\title{
WestVirginiaUniversity
}

THE RESEARCH REPOSITORY @ WVU

West Virginia Agricultural and Forestry Experiment

Davis College of Agriculture, Natural Resources

Station Bulletins

And Design

$1-1-1949$

\section{Young grass-legume silage in the poultry ration}

T. B. Clark

A. H. VanLandingham.

Charles Edward Weakley

Follow this and additional works at: https://researchrepository.wvu.edu/ wv_agricultural_and_forestry_experiment_station_bulletins

\section{Digital Commons Citation}

Clark, T. B.; VanLandingham., A. H.; and Weakley, Charles Edward, "Young grass-legume silage in the poultry ration" (1949). West Virginia Agricultural and Forestry Experiment Station Bulletins. 340.

https://researchrepository.wvu.edu/wv_agricultural_and_forestry_experiment_station_bulletins/343 @ WVU. It has been accepted for inclusion in West Virginia Agricultural and Forestry Experiment Station Bulletins by an authorized administrator of The Research Repository@WVU. For more information, please contact ian.harmon@mail.wvu.edu. 


\section{Digitized by the Internet Archive in 2010 with funding from Lyrasis Members and Sloan Foundation}




\section{BULLETIN 340}

\section{AGRICULTURAL EXPERIMENT STATION, WEST VIRGINA UNIVERSITY}

Young

Grass-Legume Silage 
Bulletin 340, September 1949

Agricultural Experintent Station, F. D. Cornell, Jr., Acting Director College of Agriculture, forestry, and Home Economics West Virginia Uninersity, Míorgantown 


\section{Young Grass-Legume Silage}

\section{in the Poultry Ration}

\section{T. B. CLARK, A. H. VanLANDINGHAM, and C. E WEAKLY, Jr.}

Departments of Animal Husbandry and Agricultural Biochemistry

The feeding of grass silage to poultry received great emphasis a few years ago. Many reports appeared in the poultry press praising this form of green feed. Grass silage was credited with stimulating the appetites of the birds, stepping up the rate of egg production, increasing hatchability and improving the health of the flock. It was also reported that the birds had redder combs than before silage was fed and that the breeding flocks came back into production quicker after molt through the feeding of grass silage.

Early work at this station by Atwood (1922) showed that corn silage had but little feeding value for layers. The ensiling of immature cereals, grasses, and legumes, however, offered new possibilities. This form of silage had the possibility of being a pasture substitute throughout the winter months. If properly ensiled it should carry fairly large amounts of such essential vitamins as carotene and riboflavin as well as other factors existing in grasses and legumes.

Allen and co-workers (1940) at the Tennessee Agricultural Experiment Station presented evidence indicating that when a legume silage was fed with a low quality ration, beneficial results were obtained. The silages used were made from red clover, alfalfa, and sericea. The basal ration was not fortified with any of the usual vitamin supplements. Beneficial results were reported for growing cockerels, ducks, and laying hens. The hens and cockerels were confined in cages with wire floors so that they did not come in contact with their droppings. The significance of this will be discussed later. The conditions for the ducks were not described. According to these workers, the feeding of the silage increased feed consumption, increased body weight, and provided a better physical condition as suggested by appearance, egg production, and post-mortem examination.

Payne and Gish (1943) published the results of extensive investigations conducted in Kansas. Only the pertinent results are reviewed. In the first experiment, immature grass silage was fed and no beneficial effect on egg production or hatchability was obtained. In another experiment, the feeding of fresh grass followed by silage resulted in higher egg production than that obtained from alfalfa meal and semisolid buttermilk but the egg production of both lots was less than that from the lot fed green grass and semisolid buttermilk. Hatchability was about the same from all these lots. The feeding of grass silage at the rate of 
four pounds daily per 100 hens produced olive-colored yolks. No more off-colored yolks were laid when fresh chopped oats were substituted for the silage.

Taylor et al. (1944), fed silage made from lawn grass clippings to chicks from day-old to seven or eight weeks of age. While their silage was of good quality and was a good source of protein, carotene, and riboflavin, the chicks could not consume enough for normal growth when fed with a ration deficient in riboflavin.

Platt (1947) reported the results of experiments in which silage made from lawn grass clippings was fed to adult chickens. When fed daily at the rate of five pounds for 100 layers, the silage apparently could be used as a substitute for dried skim milk and alfalfa meal with comparable results in the percentage hatch of fertile eggs. The silage had little influence on feed utilization, suggesting that it did not replace any of the mash and grain.

\section{EXPERIMENTAL WORK AT THE WEST VIRGINIA STATION}

Preliminary studies were started with turkeys reared in confinement in 1938. Silage made from lawn grass clippings with molasses was fed from 16 weeks to market age. The turkeys readily consumed as much as 18 pounds per 100 turkeys per day. The efficiency of feed utilization was about the same for the two silage-fed lots as that obtained for the controls. There was little difference in feathering between the lots.

Difficulty was experienced at that time in producing a silage without a disagreeable odor and without considerable loss due to mold. Therefore, all feeding trials were discontinued until these objections could be overcome.

The results presented in this report deal with the feeding of silage to chickens during the war years when a search was being made to find methods for improving supposedly low-quality rations.

\section{Preparation of the Silages}

The silages used in these studies were made from immature oats, in the first and second joint stage, blue grass lawn clippings, alfalfa, and red clover. In most cases the legumes were second cuttings in the early bloom stage. The grasses and legumes were put through an ensilage cutter and then packed into drums.

In the earlier work with turkeys, the silage was made in wooden barrels. In spite of all precautions a large amount of spoilage occurred at the top and around the bulge and the silage had a disagreeable odor. When the present trials were started in 1942, it had been found that by using straight-sided steel drums with tight lids, most of these difficulties were overcome. The silages were packed in these drums as soon as possible after cutting to prevent wilting. About five gallons of water were added to each drum to facilitate packing and exclusion of air. When molasses was added, it was mixed with the water. The groove in the lid of the drum was filled with roof putty and the lid clamped on with a levered hoop. These conditions produced a sweet smelling silage even when a preservative was not used. 
Table 1. Analyses of Silages Used in 1943-44 Trials.

\begin{tabular}{|c|c|c|c|c|c|c|}
\hline SILAGE & $\begin{array}{l}\text { SAMPLE } \\
\text { NUMBER }\end{array}$ & $\begin{array}{c}\text { DRY } \\
\text { MATTER }\end{array}$ & PROTFIN" & CAROTENE & $\begin{array}{c}\text { RIBO- } \\
\text { FLAVINT }\end{array}$ & $\mathrm{pH}$ \\
\hline \multicolumn{7}{|c|}{ (percent) } \\
\hline Oats $+10 \mathrm{lb}$. molasses..... & .. 202 & 11.0 & 13.05 & 87 & 10 & 3.8 \\
\hline Oats +8 lb. corn meal..... & . . 204 & 10.1 & 14.35 & 242 & 10 & 4.2 \\
\hline Red Clover + 15 lb. molasses. & .. 206 & 23.0 & 13.36 & 146 & 12 & 3.7 \\
\hline Red Clover +9 lb. dried whey & $\ldots 208$ & 19.9 & 14.39 & 96 & 14 & 3.6 \\
\hline Lawn clippings + molasses. . & $\ldots$ & 25.9 & 17.40 & 347 & 15 & 5.0 \\
\hline Lawn clippings + corn meal. & $\ldots$ & 28.6 & 19.65 & 329 & 16 & 4.8 \\
\hline
\end{tabular}

- Percentage of protein in dry matter.

$\dagger$ Micrograms per gram of dry matter.

Table 2. Analyses of Silages Used in 1944-45 Trials.

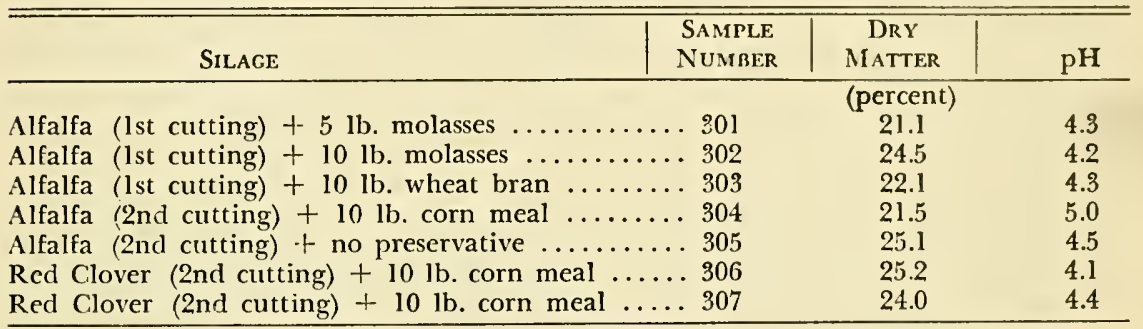

The various silages used together with certain analyses are shown in Tables 1 and 2. Silage from lawn clippings was not used in the feeding trials reported here, but the analyses are included to show that this is a better source of protein and vitamins than the silages used.

\section{Growth Trials}

The growth trials were conducted to determine the value of immature silages as a supplement to starting and growing rations low in riboflavin and vitamin $\mathrm{A}$. The growing rations are given in Table 3. The rations used in the chick trials were mixed to contain 18 percent protein and in the growing period to contain 16 percent. The percentage of protein was increased for the starting period by substituting appropriate amounts of soybean oil meal for corn meal.

Chick Growth Trials - These trials were conducted with White Leghorn chicks in battery brooders. The chicks were fed Ration 4 during the first two weeks of age to deplete them of riboflavin reserves. At the end of this period the chicks were distributed at random among the battery brooders with two lots of 10 chicks per lot assigned to each ration. The test rations were fed for four weeks. There was no mortality during this period.

The silage used in these trials was No. 204, Table 1, made from immature oats just passed the first joint stage. When opened, the silage was bright in color and in good condition. To prevent mold during 
Table 3. Starting and Growing Mash Formulas.

\begin{tabular}{|c|c|c|c|c|}
\hline \multirow[b]{2}{*}{ INGREDIENTS } & \multicolumn{4}{|c|}{ RATIONS } \\
\hline & Lot 1 & Lot $2^{*}$ & LOT 3 & Lot $4 t$ \\
\hline & (percent) & (percent) & (percent) & (percent) \\
\hline Ground yellow corn & . 41.4 & 44.4 & 41.8 & 44.4 \\
\hline Wheat standard middlings $\ldots \ldots \ldots$. & . 20.0 & 20.0 & 20.0 & 20.0 \\
\hline Wheat bran $\ldots \ldots \ldots \ldots \ldots \ldots \ldots$ & . . 10.0 & 10.0 & 10.0 & 10.0 \\
\hline Ground oats $\ldots \ldots \ldots \ldots \ldots \ldots$ & . 10.0 & 10.0 & 10.0 & 10.0 \\
\hline Alfalfa meal $\ldots \ldots \ldots \ldots \ldots \ldots \ldots$ & .. 4.0 & .. & ‥ & ... \\
\hline Curbay $B-G \quad \ldots \ldots \ldots \ldots \ldots \ldots \ldots$ & .. $\ldots$ & $\cdots$ & 2.5 & $\ldots$ \\
\hline Meat scraps $(55 \%$ protein $) \ldots .$. & .. 3.0 & 3.0 & 3.0 & 3.0 \\
\hline Soybean oil meal $\ldots \ldots \ldots \ldots \ldots \ldots$ & .. 8.0 & 9.0 & 9.0 & 9.0 \\
\hline Bone meal $\ldots \ldots \ldots \ldots \ldots \ldots \ldots \ldots$ & .. 1.0 & 1.0 & 1.0 & 1.0 \\
\hline Pulverized limestone...$\ldots \ldots \ldots$ & . $\quad 2.0$ & 2.0 & 2.0 & 2.0 \\
\hline D-activated animal sterol $\ldots . .$. . & .. 0.1 & 0.1 & ‥ & 0.1 \\
\hline Codliver oil concentrate $\ldots \ldots \ldots \ldots \ldots$ & $\ldots \ldots$ & ... & 0.2 & . \\
\hline Salt + manganese...$\ldots \ldots \ldots \ldots$ & . 0.5 & 0.5 & 0.5 & 0.5 \\
\hline & 100.0 & 100.0 & 100.0 & 100.0 \\
\hline
\end{tabular}

* Ration fed to Lot 2 was supplemented with silage.

$\dagger$ Bluegrass pasture, available to growing pullets, 8 to 20 weeks of age.

Table 4. Growth Trials with Chicks, 2 to 6 Weeks of Age.

\begin{tabular}{c|l|c|c}
\hline \hline \multirow{2}{*}{ Lot } & Supplemf.nTs & Av. WEIGHT AT & CURLED-TOFS \\
\hline & & WEEKs OF AGE & (percent) \\
1 & Alfalfa meal & 309 & 0 \\
2 & Silage & 294 & 20 \\
3 & Ribo. Conc. & 358 & 0 \\
4 & No Supp. & 280 & 25 \\
\hline
\end{tabular}

the hot weather while these trials were in progress, the silage was stored in a cooler held at about $35^{\circ} \mathrm{F}$.

The results from these trials are given in Table 4 . The average body weight of Lot 3 , the positive control, significantly exceeds the average weight of the other three lots. The results show that the rations fed to Lots 2 and 4 were deficient in riboflavin. The alfalfa meal in the ration of Lot 1 provided sufficient riboflavin to prevent curled toes, but not enough to support maximum growth. The fact that curled toes did not appear is not sufficient proof that riboflavin was available in quantities necessary to provide maximum growth.

The chicks in Lot 2 were fed an amount of finely cut silage that they would consume in about four hours each day. The results show, however, that they were unable to consume sufficient silage at this age to prevent a riboflavin deficiency. This is in accord with the results obtained by Taylor et al. (1944). These workers used grass clippings, which should have been a better source of vitamins than the oats used in these trials. Their work was published while these trials were in progress and this phase of our work was discontinued.

Pullet Growth Trials - These trials were conducted with White Leghorn pullets, starting at 8 weeks of age and continued for 12 weeks. 
Table 5. Growth Trials with Pullets, 8 to 20 Weeks of Age.

\begin{tabular}{|c|c|c|c|c|}
\hline Lot & SUPPLEMENTS & $\mid \begin{array}{c}\text { Av. WEIGHT AT } \\
20 \text { WLEKS OF AGE }\end{array}$ & $\begin{array}{l}\text { FLL.D PlR LB. } \\
\text { OF GAIN }\end{array}$ & .IORI.UITY \\
\hline \multirow{3}{*}{1} & & (lb.) & (Ib.) & (perecut) \\
\hline & AIfalfa & & & \\
\hline & meal & 2.97 & 7.36 & 4.6 \\
\hline 2 & Silage & 3.01 & $8.06^{*}$ & 4.6 \\
\hline 3 & Ribo. Conc. & 3.08 & 7.92 & 10.6 \\
\hline \multirow[t]{2}{*}{4} & Bluegrass & & & \\
\hline & pasture & 3.08 & 7.66 & 1.5 \\
\hline
\end{tabular}

* This does not include silage.

The all-mash rations are given in Table 3 . The first three lots were confined to colony houses with sun porches, while Lot 4 was allowed access to a bluegrass range. Each lot contained 65 pullets at the start. Oat silage, No. 202, was fed to Lot 2 in these trials. The amount fed was based on a four-pound pullet eating one-half ounce per day. This small amount was based on preliminary trials and was about all the pullets would "clean up" without wastage.

The results in Table 5 show that all lots were similar in average body weight at 20 weeks of age. The oat silage apparently provided sufticient carotene to maintain growth. The birds had access to the litter which may have provided them with sufficient riboflavin. The feed efficiency values (pounds of feed consumed per pound of gain in body weight) show no advantage for the silage. It is of interest to note that the range lot (No. 4) consumed slightly more feed per unit of gain than did Lot 1. This result is not unusual. Growing bircls do not consume much grass unless the ration is restricted and the grass is green and growing. This was an ordinary bluegrass pasture which became dry and brown during the hot weather. No attempt was made to clip it except to allow sheep access to this area.

\section{Laying Trials, Experimen: 1, 1943-44}

It had been observed previously that immature grass silages seemed to be relished by poultry of all ages in confinement. No information was available, however, on the amount the layers would consume without affecting egg production. Accordingly, a clrum of alfalfa silage was chosen from several samples for feeding. It had a green color but the odor was strong, resembling that of silage made in a large silo. In order to determine how much silage 50 White Leghorn pullets would eat, the daily feeding was gradually increased in the month of November. When the rate of feeding reached $21 / 2$ pounds of silage per day in December, 1942, egg production dropped sharply below that of the control pen and nine of the fifty pullets suddenly died. The silage was reduced to $11 / 4$ pounds per day to this pen and the egg production slowly increased. The egg production never did reach the level of the control pen. No further abrupt mortality occurred. 
Table 6. Typical All-Mash Laying Rations Used in 1943-44.

\begin{tabular}{|c|c|c|c|}
\hline \multirow[b]{2}{*}{ INGREDIENTS } & \multicolumn{3}{|c|}{ Rations } \\
\hline & PENS 1 \& $2^{*}$ & PENS 3 \& 4* & $\operatorname{PEN} 5 *$ \\
\hline & (percent) & (percent) & (percent) \\
\hline Ground yellow corn & $\ldots 15.00$ & $15.00^{\prime}$ & 15.00 \\
\hline Ground barley ..... & $\ldots 26.75$ & 26.75 & 26.75 \\
\hline Ground oats $\ldots \ldots$ & $\ldots 10.00$ & 10.00 & 10.00 \\
\hline Wheat bran ........ & $\ldots 10.00$ & 10.00 & 10.00 \\
\hline Wheat standard midd & $\ldots 25.00$ & 27.50 & 28.50 \\
\hline Alfalfa meal (dehydra & $\ldots \quad 2.50$ & - & $\cdots$ \\
\hline Curbay B-G ......... & ... 1.00 & 1.00 & $\cdots$ \\
\hline Meat scrap (55\% prot & .. 2.50 & 2.50 & 2.50 \\
\hline Soybean oil meal .... & .. 2.50 & 2.50 & 2.50 \\
\hline Bone meal ......... & ... 2.00 & 2.00 & 2.00 \\
\hline Pulverized limestone & .. 2.00 & 2.00 & 2.00 \\
\hline Codliver oil (400-D) & $\ldots \quad 0.25$ & 0.25 & 0.25 \\
\hline Salt + manganese ... & . $\quad 0.50$ & 0.50 & 0.50 \\
\hline & 100.00 & 100.00 & 100.00 \\
\hline
\end{tabular}

- Pens 2, 4, and 5 were fed silage.

Table 7. Results from Two Laying Trials, 1943-44 and 1944-45.

\begin{tabular}{|c|c|c|c|c|}
\hline PENS & $\begin{array}{l}\text { INITIAL } \\
\text { NUMBER }\end{array}$ & Mortality & $\begin{array}{l}\text { AVERAGE } \\
\text { INITIAL } \\
\text { WEIGHT }\end{array}$ & $\begin{array}{c}\text { AVERAGE } \\
\text { FINAL } \\
\text { WEIGHT }\end{array}$ \\
\hline \multicolumn{5}{|c|}{ 1943-44 (LEGHORNS) } \\
\hline $\begin{array}{l}1 \\
2 \\
3 \\
4 \\
5\end{array}$ & $\begin{array}{r}100 \\
100 \\
50 \\
50 \\
46\end{array}$ & $\begin{array}{c}\text { (percent) } \\
18.0 \\
12.0 \\
8.0 \\
6.0 \\
15.2\end{array}$ & $\begin{array}{l}\text { (lb.) } \\
3.4 \\
3.5 \\
3.3 \\
3.3 \\
3.4\end{array}$ & $\begin{array}{l}\text { (lb.) } \\
3.5 \\
3.4 \\
3.4 \\
3.3 \\
3.5\end{array}$ \\
\hline \multicolumn{5}{|c|}{ 1944-45 (NEW HAMPSHIRES) } \\
\hline $\begin{array}{l}1 \\
2 \\
3 \\
4\end{array}$ & $\begin{array}{l}92 \\
86 \\
92 \\
92\end{array}$ & $\begin{array}{r}9.8 \\
10.5 \\
14.1 \\
9.8\end{array}$ & $\begin{array}{l}5.1 \\
5.2 \\
5.1 \\
5.1\end{array}$ & $\begin{array}{l}5.7 \\
5.8 \\
5.7 \\
5.7\end{array}$ \\
\hline
\end{tabular}

With these observations in mind, five pens of White Leghorn pullets were started on the laying trials in the following year and fed the all-mash rations as indicated in Table 6 . Silage was fed at the rate of $21 / 2$ pounds per 100 pullets per day to Pens 2, 4, and 5. Pens 1 and 2 were fed a complete ration. The ration fed Pens 3 and 4 contained no alfalfa meal. The ration fed Pen 5 contained neither alfalfa meal nor riboflavin concentrate (Curbay B-G).

The number of pullets in each pen, the body weight, and the total mortality are given in Table 7 for the 1943-44 trials. Pen 5 does not have a control for comparison and is included only to show the results on yolk color and hatchability.

The silage fed to these pens was made in tightly sealed steel drums as previously explained and appeared to be of excellent quality. Im- 
Table 8. Egg Production, October 18, 1943 to May 28, 1944, And Yolk Color Index for LAST Four Perions.

\begin{tabular}{|c|c|c|c|c|c|}
\hline PERIOD* & PEN 1 & PEN 2 & PEN 3 & PEN 4 & PEN 5 \\
\hline \multicolumn{6}{|c|}{ FGg Production } \\
\hline & (percent) & (percent) & (percent) & (percent) & (percent) \\
\hline l & 40.9 & 48.5 & 32.8 & 40.6 & 40.0 \\
\hline 2 & 24.2 & 21.2 & 17.6 & 31.1 & 26.7 \\
\hline 3 & 43.3 & 43.4 & 49.1 & 55.1 & 40.2 \\
\hline 4 & 54.4 & 54.4 & 62.0 & 58.5 & 57.2 \\
\hline 5 & 43.8 & 35.9 & 47.2 & 39.7 & 43.8 \\
\hline 6 & 52.1 & 46.5 & 50.3 & 55.5 & 56.1 \\
\hline 7 & 62.1 & 61.6 & 62.8 & 62.3 & 67.4 \\
\hline 8 & 60.8 & 59.3 & 65.5 & 61.5 & 62.1 \\
\hline Average & 47.7 & 46.3 & 48.4 & 50.5 & 49.2 \\
\hline \multicolumn{6}{|c|}{ YOLK COLOR INDEX } \\
\hline 5 & 11.9 & 12.7 & 10.6 & 12.6 & 12.2 \\
\hline 6 & 12.3 & 12.8 & 11.3 & 12.0 & 11.6 \\
\hline 7 & 12.3 & 12.6 & 10.9 & 12.0 & 12.0 \\
\hline 8 & 12.0 & 12.0 & 10.5 & 11.0 & 10.6 \\
\hline Average & 12.1 & 12.5 & 10.8 & 11.9 & 11.6 \\
\hline
\end{tabular}

* Periods of 28 days.

mature oat silage (No. 204) was fed during the first four periods and second-cutting red clover silage (No. 206 and No. 208) during the second four periods.

EGG Production - The percentage of egg production values for the eight 28-day periods are presented in Table 8 . These values were calculated on a hen-day basis. The average values suggest little or no difference in egg production among the five pens. Comparing Pens 1 with 2 , and 3 with 4 , the differences in the percentage values are not significant. Although Pen 5 did not have a negative control, apparently these pullets laid as well as the others.

YOLK COLOR - Observations on yolk color were made on all of the eggs laid for two successive days during each of the last four periods. The yolk color indexes were obtained by comparing the broken-out yolks with the colors on a Heiman-Carver Color Roter. Each color on the roter was assigned a number starting at 1 for the lightest color.

The yolk color values are given in Table 8 . The feeding of silage apparently produced a slightly darker colored yolk in pens 2, 4, and 5 . The effect was more pronounced in Pens 4 and 5 than in Pen 2 because the ration fed to Pens 4 and 5 did not contain any alfalfa meal. The higher values obtained for Pens 1 and 2 apparently resulted from the alfalfa meal in this ration.

Blood and Meat Spots - When the yolk color comparisons were being made, the number of eggs containing blood and meat spots was recorded. The percentages of blood and meat spots found in the eggs from Pens 1 to 5 were 7.6, 6.8, 2.5, 4.2, and 3.6, respectively. These results show that the silage fed to these layers did not contain the factor supposedly contained in grass for the prevention of blood and meat spots. 
Table 9. Summary of Hatchability Studies - Experiment 1, 1943-44.

\begin{tabular}{|c|c|c|}
\hline DATE & NuMber & PERCENT \\
\hline НАTCHED & JERTILE & HATCHED \\
\hline Feb. 19 & 112 & 68.7 \\
\hline \multirow[t]{2}{*}{ June 6} & 222 & 60.8 \\
\hline & & Av. 64.7 \\
\hline Aug. $8^{*}$ & 136 & 70.6 \\
\hline
\end{tabular}

\begin{tabular}{c|c|c}
\multicolumn{3}{c}{ PEN 2 } \\
\hline DATE & NuMBer & PERCENT \\
HATChed & FERTILE & HatChed \\
\hline Feb. 19 & 112 & 83.9 \\
June 6 & 223 & 65.9 \\
Aug. 8* & 143 & Av. 74.9 \\
\hline
\end{tabular}

PEN 3

\begin{tabular}{c|cc}
\hline \hline DATE & NuMBer & Percent \\
HatChed & FerTILE & HATCHED \\
\hline Feb. 19 & 159 & 81.8 \\
June 6 & 224 & 79.5 \\
& & Av. 80.6 \\
Aug. 8* & 144 & 60.4 \\
\hline
\end{tabular}

PEN 4

\begin{tabular}{l|c|c}
\hline \hline DATE & NUMBER & PERCENT \\
HATCHED & FERTILE & HATCHED \\
\hline Feb. 19 & 118 & 84.7 \\
June 6 & 222 & 73.0 \\
& & Av. 78.8 \\
Aug. 8* & 120 & 71.7 \\
\hline
\end{tabular}

PEN 5

\begin{tabular}{l|cc}
\hline DATE & $\begin{array}{c}\text { NUMBER } \\
\text { FERTILE }\end{array}$ & $\begin{array}{c}\text { PERCENT } \\
\text { HATCHED }\end{array}$ \\
\hline HaTCHED & 87 & 75.9 \\
June 6 & 223 & 57.5 \\
& & Av. 66.7 \\
Aug. 8* & 135 & 52.6 \\
\hline Following treatment.
\end{tabular}

Hatchability - The males were rotated at intervals among the pens prior to and during the time the eggs were saved for incubation. Three hatches were taken off as indicated in Table 9; the first two during the silage feeding period and the third seven weeks after the silage feeding had been discontinued.

The number of fertile eggs set and the percentage of fertile eggs hatched are given in Table 9. Considering the variability of the three hatches for each pen, there is little evidence that silage had any effect on hatchability. In Pens 1 and 2, the hatchability increased after the silage feeding had been discontinued. There was a steady downward trend for the hatchability of Pen 5 showing that if the ration were deficient in riboflavin, it was not supplemented by the silage. Since the birds had access to the litter, however, it is believed that this decline was not the result of a vitamin deficiency.

\section{Laying Trials, Experiment 2, 1944-45}

These laying trials were conducted with New Hampshire pullets, derived from several strains. The pullets were divided among the laying pens according to strain and body weight. They were housed in $20^{\prime}$ by $20^{\prime}$ pens in the same house. The three rations used are given in Table 10. These differed slightly in cereal content from the all-mash rations used during the previous year and whole instead of ground oats was used. As in the previous year, Ration 1 was the control. Alfalfa meal was omitted from Ration 2 and both alfalfa meal and the riboflavin concentrate were omitted from Ration 3. 
Table 10. Typigal All-mash Laying Rations Used in 1944-45.

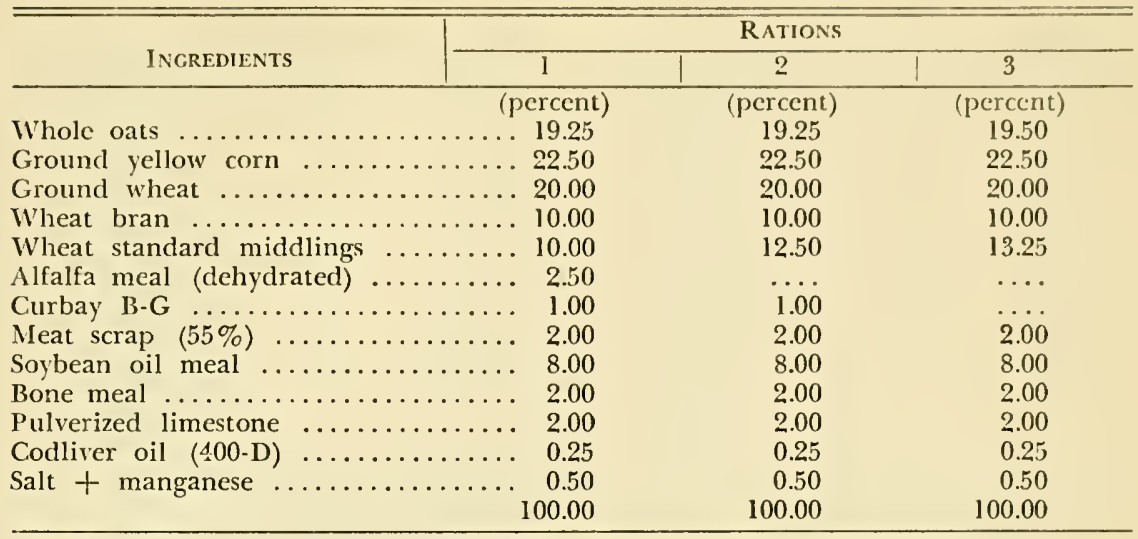

The silage was fed daily from the beginning of the laying trials to Pens 2, 3, and 4. The amount was increased gradually from one pound to three pounds daily for each 100 pullets. This rate was continued during the remainder of the nine 28-day periods.

The rations and silages were rotated at regular intervals among Pens 2, 3, and 4. Pen 1, the control, was fed only Ration 1 throughout the experiment. The rations for Pens 2, 3, and 4 were rotated at the end of the third and sixth periods as shown in Table 11. Two kinds of silage, starting with alfalfa, were fed within each three periods. Thus each ration change was accompanied by the feeding of both kinds of silage, alfalfa, and red clover. The data on the silages used are given in Table 2.

The number of pullets started and the initial and final body weights are given in Table 7 .

EgG Pronuction - The percentage of production by periods is shown in Table 11. As might be expected from the method of rotating the rations, the pen averages for the nine periods do not differ significantly. It will be observed that the birds in Pen 4 laid well regardless of the ration fed and that the egg production from this pen increased with each change in ration. On the other hand, Pen 2 laid better while being fed Ration 3 than when fed Ration 2 in spite of the fact that the latter ration should have been more complete. These results are interpreted to mean that neither the rations nor the silage had much influence on egg production Apparently the rations were not deficient in nutrients required for egg production and the fluctuations observed were due to other factors.

Hatchability - The hatchability studies for this experiment are summarized in Table 12 . This table is set up according to ration changes. Two settings were made from each ration. The eggs were not saved for the first of each pair of hatches until four weeks after the rations had been rotated. 
Table 11. Egg Production September 18, 1944 to May 27, 1945.

\begin{tabular}{c|cc}
\multicolumn{3}{c}{ PEN 1 } \\
\hline \hline PERIOD* & RATION & Production \\
\hline 1 & 1 & (percent) \\
2 & 1 & 28.88 \\
3 & 1 & 58.62 \\
& & Av. 48.93 \\
4 & 1 & 60.64 \\
5 & 1 & 60.31 \\
6 & 1 & 59.87 \\
& & Av. 60.27 \\
7 & 1 & 60.57 \\
8 & 1 & 59.70 \\
9 & 1 & 54.69 \\
& & Av. 58.32 \\
Average for 9 periods & 55.84 \\
\hline
\end{tabular}

PEN 2

\begin{tabular}{c|cc}
\hline \hline PERIOD* & RATION & Production \\
\hline 1 & 1 & (percent) \\
2 & 1 & 59.24 \\
3 & 1 & 58.75 \\
& & Av. 47.75 \\
4 & 3 & 63.93 \\
5 & 3 & 65.55 \\
6 & 3 & 63.81 \\
& & Av. 64.43 \\
7 & 2 & 64.01 \\
8 & 2 & 58.93 \\
9 & 2 & 56.98 \\
& & Av. 59.97 \\
Average for 9 periods & 57.38 \\
\hline
\end{tabular}

\section{PEN 3}

\begin{tabular}{c|cc}
\hline PERIOD* $^{*}$ & RATION & Production \\
\hline 1 & 2 & (percent) \\
2 & 2 & 55.26 \\
3 & 2 & 58.12 \\
& & Av. 45.89 \\
4 & 1 & 58.63 \\
5 & 1 & 60.68 \\
6 & 1 & 59.10 \\
& & Av. 59.47 \\
7 & 3 & 61.36 \\
8 & 3 & 57.89 \\
9 & 3 & 54.50 \\
& & Av. 57.92 \\
Average for 9 periods & 54.42 \\
\hline
\end{tabular}

PEN 4

\begin{tabular}{ccc}
\hline \hline PERIOD* & RATION & PRODUCTION \\
\hline & & (percent) \\
1 & 3 & 27.86 \\
2 & 3 & 60.17 \\
3 & 3 & 61.96 \\
& & Av. 50.00 \\
4 & 2 & 57.10 \\
5 & 2 & 59.76 \\
6 & 2 & 61.78 \\
& & Av. 59.55 \\
7 & 1 & 65.44 \\
8 & 1 & 62.48 \\
9 & 1 & 60.94 \\
Average for 9 periods & Av. 62.95 \\
Ty
\end{tabular}

* Periods of 28 days.

The percentage of hatchability was uniform for Pen 1 throughout the experiment. In the other pens the results suggest that there was a tendency for the hatchability to vary with the ration fed although the variation for all periods is not marked. The hatchability for the last hatch, four weeks after silage feeding was stopped, was slightly lower for Pens 2 and 3 than for the other pens. Since there was a decrease for all pens in this period, however, there is little evidence that the lack of silage produced this effect.

\section{Discussion of Results}

The results obtained from the limited growth trials with chicks agree with those obtained by the New Jersey workers. The chicks simply did not consume enough silage to supplement their diet. Different results were expected, however, from the growing pullets as well as from the laying stock. In the older groups it is possible that the birds likewise did not consume enough silage for any supplemental effects. Under 
Table 12. Summary of Hatchability Studies - Experiment 2, 1944-45.

\begin{tabular}{|c|c|c|c|}
\hline RATION & $\begin{array}{c}\text { DATE } \\
\text { HATCHED }\end{array}$ & $\begin{array}{l}\text { NuMiBER } \\
\text { FERTILE }\end{array}$ & $\begin{array}{l}\text { P'LRCENT } \\
\text { HATCHED }\end{array}$ \\
\hline \multirow{3}{*}{1} & Dec. 6 & 189 & 82.5 \\
\hline & Ian. 2 & 182 & 82.4 \\
\hline & Feb. 13 & 189 & Av. $\begin{array}{r}82.5 \\
83.6\end{array}$ \\
\hline \multirow[t]{2}{*}{ I } & Mar. 26 & 227 & 84.1 \\
\hline & May 8 & 207 & Av. 83.9 \\
\hline \multirow[t]{2}{*}{1} & June 18 & 188 & 80.8 \\
\hline & July $18^{*}$ & 182 & 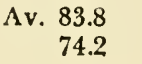 \\
\hline
\end{tabular}

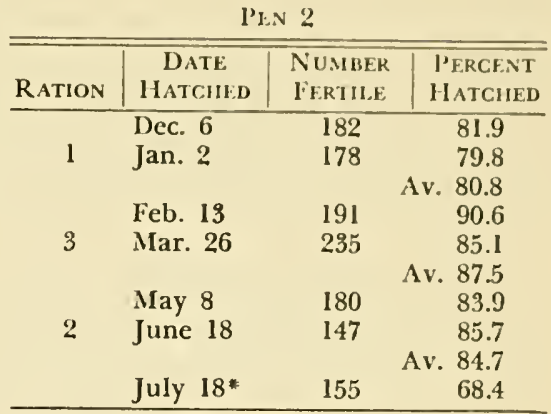

PEN 3

\begin{tabular}{|c|c|c|c|}
\hline RATION & $\begin{array}{c}\text { DATE } \\
\text { HATCHED }\end{array}$ & $\begin{array}{l}\text { NUMBER } \\
\text { FERTILE }\end{array}$ & $\begin{array}{l}\text { PERCENT } \\
\text { HATCHED }\end{array}$ \\
\hline \multirow{3}{*}{2} & Dec. 6 & 185 & 82.7 \\
\hline & Jan. 2 & 171 & 83.6 \\
\hline & Feb. 13 & 183 & 84.1 \\
\hline \multirow[t]{2}{*}{1} & Mar. 26 & 230 & 86.5 \\
\hline & May 8 & 188 & 82.4 \\
\hline \multirow[t]{2}{*}{3} & June 18 & 154 & 85.1 \\
\hline & July $18 *$ & 185 & 69.1 \\
\hline
\end{tabular}

\begin{tabular}{|c|c|c|c|}
\hline RATION & $\begin{array}{c}\text { DATE } \\
\text { HATCHED }\end{array}$ & $\begin{array}{l}\text { NuMber } \\
\text { Fertille }\end{array}$ & $\begin{array}{l}\text { PERCENT } \\
\text { HATChED }\end{array}$ \\
\hline \multirow{3}{*}{3} & Dec. 6 & 194 & 71.1 \\
\hline & Jan. 2 & 181 & 73.5 \\
\hline & Feb. 13 & 193 & 89.6 \\
\hline \multirow[t]{2}{*}{2} & Mar. 26 & 239 & 88.7 \\
\hline & May 8 & 230 & 87.4 \\
\hline \multirow[t]{2}{*}{1} & June 18 & 199 & 85.4 \\
\hline & July $18^{*}$ & 195 & 71.3 \\
\hline
\end{tabular}

* Following treatment.

the conditions of this experiment it is doubtful whether the diets were deficient in riboflavin when the birds had access to litter.

There were no negative control pens used in these laying trials. In other words, the rations were supplemented with either riboflavin concentrate, alfalfa meal, or silage. When these experiments were planned, negative controls were considered unnecessary because previous experience with rations low in riboflavin resulted in lowered hatchability. An important change had occurred, however, during the war years in litter management. In these trials the litter was not changed during the laying year. Only wet litter around the water fountains was replaced with dry litter. A build-up litter was being used without realizing its importance.

Reccntly the Ohio Experiment Station (Kennard, et al., 1948) compared the use of built-up litter with litter changed every two weeks. A basal ration was used containing no animal protein supplement and only five pounds of alfalfa meal as a riboflavin carrier. The hatchability from the lot where the litter was changed every two weeks was 33 percent and on the built-up litter 78 percent. The latter value was comparable with that obtained from a ration containing animal protein and milk by-products. 
It is now known that riboflavin is synthesized in the droppings when the temperature is favorable. Since the rations used in these trials were supposedly deficient only in riboflavin, this explains the lack of any cliange in hatchability other than seasonal when the silage feeding was discontinued. This knowledge together with the Ohio results suggests that certain deficiencies in the ration may be overcome satisfactorily by litter management. The use of deep built-up litter in these trials apparently had as much influence on hatchability as did the all-mash rations.

There was no evidence in any of the trials that silage feeding had an effect on livability. The health of the birds appeared to be uniformly good in all lots. This is suggested by the percentages of mortality for the birds in the laying trials as shown in Table 7.

\section{Summary and Conclusions}

Silage was made from immature oats, red clover, and alfalfa and preserved in steel drums. Equally good results were obtained when the silage was made with or without a preservative.

A basal chick ration, deficient principally in riboflavin, produced slow growth and curled-toe paralysis even when supplemented with silage. Chicks reared in batteries from 2 to 6 weeks of age could not consume sufficient silage to overcome the deficiency.

In trials with growing pullets, from 8 to 20 weeks, and using the same basal chick ration, the addition of silage had no apparent beneficial effect except to prevent a possible deficiency in carotene.

Egg production was not affected when silage was fed at the rate of 2.5 to 3 pounds per 100 hens per day with a complete all-mash ration or with rations from which either or both alfalfa meal or riboflavin concentrate had been omitted. The egg yolks were slightly darker when silage was fed with the ration containing alfalfa meal. The silage feeding had no apparent effect on the percentage of blood spots.

There was no relation between silage feeding and mortality in either the growing or laying trials.

There was little or no indication that silage feeding had any effect on hatchability. The change in hatchability resulting when silage feeding was discontinued for four or more weeks in the summer months could not be attributed to the silage.

Considering the labor involved in making immature silage and the cxperimental evidence showing little or no beneficial results from feeding the silage to chicks in batteries, to growing pullets and layers confined in pens, it is concluded that the poultry ration can be supplemented more efficiently by other vitamin carriers, especially for supplying riboflavin. 


\section{REFERENCES}

Allen, P. W., M. Jacob, N. O. Syolander, and J. A. McBee, 1940. Legume Silage as a Poultry Feed. Tenn. Agr. Exp. Sta., Bul. 172.

Atwood, Horace, 1922. Effect of Confinement and Green Feed on Number and Hatchability of Eggs. W. Va. Agr. Exp. Sta., Bul. 178. Kennard, D. C., R. M. Bethke, and V. D. Chamberlain, 1947. Builtup Floor Litter May Improve the Hatch. Farm and Home Research. 33:17. Ohio Agr. Exp. Sta.

Payne, Loyal F., and Clarence L. Gish, 1943. Grass and Alfalfa as Silage, Forage and Meal for Poultry. Kansas Agr. Exp. Sta., Bul. 320.

Platt, C. S., 1947. Grass Silage and Green Feed in the Poultry Diet. New Jersey Agr. Exp. Sta., Bul. 734.

Taylor, M. W., W. C. Russel, and C. S. Platt, 1944. The Value of Grass Clippings Silage for the Growing Chick. Poultry Sci., 23:213. 

